\title{
Growth performance and cost efficiency of tilapia (Oreochromis niloticus) and milkfish (Chanos chanos) fed extruded floating and non-floating feeds reared in net cages in Taal Lake
}

\author{
Frederick B. Muyot ${ }^{* 1}$, Maria Theresa M. Mutia ${ }^{1}$, Paul John H. Caunan ${ }^{1}$ \\ ${ }^{1}$ National Fisheries Research and Development Institute-Freshwater Fisheries Research and Development Center, Butong, \\ Taal, Batangas, Philippines
}

\section{A B S T R A C T}

This study evaluated the growth and cost efficiency of tilapia (Oreochromis niloticus) and milkfish (Chanos chanos) fed three feed types used in cage farming in Taal Lake, Batangas, Philippines to serve as baseline information for cage aquaculture regulations. O. niloticus and C. chanos were reared in net cages fed three feed treatments: extruded floating feed (EFF), slow-sinking feed (SSF), and sinking feed (SF). Growth performance, feed conversion ratio (FCR), yield, and cost efficiency were compared at harvest. Results of the study showed that EFF had significantly higher mean weight gain, absolute growth and specific growth rate, biomass harvest, percentage good size fish, and FCR than SF in both O. niloticus and C. chanos $(\mathrm{P}<0.05)$, but had no significant difference with SSF in terms of growth parameters $(\mathrm{P}>0.05)$. FCR and biomass harvest were significantly higher in EFF than $\mathrm{SF}$ in $O$. niloticus $(\mathrm{P}<0.05)$ but were not statistically different in C. chanos $(\mathrm{P}>0.05)$. Survival rate was not significantly different among feed types $(\mathrm{P}>0.05)$ in both species. Net profit was significantly higher in EFF than the other feed types $(\mathrm{P}<0.05)$. At the same volume of fish production in the lake, the use of extruded floating feeds in cages lessened the feed cost by $17.91-29.44 \%$ for higher net returns and decreased feeds use by $19.64-30.0 \%$, which could minimize negative impacts on the lake water environment. The results of the study revealed the comparative advantage of floating feeds over slow-sinking feeds and sinking feeds and is therefore recommended as the ideal feed type for cage farming in the lake.

E-mail address: fredbmuyot@yahoo.com ${ }^{*}$

Received: October 2, 2018; Accepted: December 28, 2018
Keywords: extruded floating feeds, slow sinking feeds, sinking feeds, growth performance, cage aquaculture

\section{I N T R O D UCT I O N}

$\mathbf{T}$ he Philippines ranked 11th among aquaculture producing countries in the world in 2015 with a production of 781,798 metric tons valued at US\$ 1.87B (FAO 2017). Milkfish (Chanos chanos) and tilapia (Oreochromis niloticus) are the 2nd and 3 rd among cultured species produced in the country with a combined production of 657,133 metric tons in 2016 (BFAR Fisheries Profile 2016) with a percentage share of $82.51 \%$ of aquaculture production excluding seaweeds. Among culture environments in the country, inland waters, particularly lakes, are rapidly becoming the major source of production for aquaculture with 97,568 metric tons production in 2016 (BFAR Philippines Fisheries Profile 2016) representing $12.25 \%$ of the national aquaculture production. Taal Lake, the third largest lake in the country, is one of the important freshwater inland waters because of the rapid development and expansion of cage aquaculture. It is now a major producer of $O$. niloticus and C. chanos in the country with 72,393 metric tons of O. niloticus and 12,880 metric tons C. chanos produced in 2016 (BFAR Philippine Fisheries Profile 2016; PSA 2016). This represents about $6.07 \%$ of the total aquaculture production in the country and specifically, $27.95 \%$ of O. niloticus and $3.24 \%$ C. chanos.

The rapid development of cage aquaculture in inland waters such as Taal Lake has led to a significant contribution to fisheries production. However, the large volume of production in these aquatic environments also reflects the high volume of feeds used for rearing fish, a major concern for Taal Volcano Protected Landscape-Protected Landscape Management Board (TVPL-PAMB), the management board overseeing Taal Lake and its watershed. Feeds is 
a major input in intensive cage culture system which is one of the potential contributors of organic loading in the lake. When improperly managed by fish farmers and left unchecked and unregulated by appropriate authorities, feeds may lead to degradation of water quality of the lake and result in fish kills. White (2013) stated that poor feed quality and poor feeding strategy have major influences on the environmental impact for shore-based and open-water farming system. Several studies have shown that increased production of cultured species fed artificial diets resulted in higher levels of ammonia and decreased dissolved oxygen level (Jescovitch 2017; Mmochi et al. 2002) and may affect fish culture. It is therefore important that the impact of aquaculture feeds in the environment be minimized through the use of efficient, environmentfriendly diets, and employing optimum feeding strategies (Tacon and Forster 2003; White 2013).

As feed is the main input in cage aquaculture that may affect lake water quality, specific guidelines in the TVPL Management Plan in its Unified Rules and Regulation for Fisheries (URFF) Section 6 stated that extruded floating feeds must be employed in cage aquaculture in the lake (TVPL 2010). Extruded feeds are known to be efficient and contribute less to water quality degradation. The use of extruded feeds in aquaculture is known to be more environment-friendly and efficient than conventional pressed sinking pellets (Ammar 2008; Ammar et al. 2008; Robert et al. 1993; Venou et al. 2003; Hilton et al. 1981). Moreover, in the case of inland water aquaculture such as in lakes,

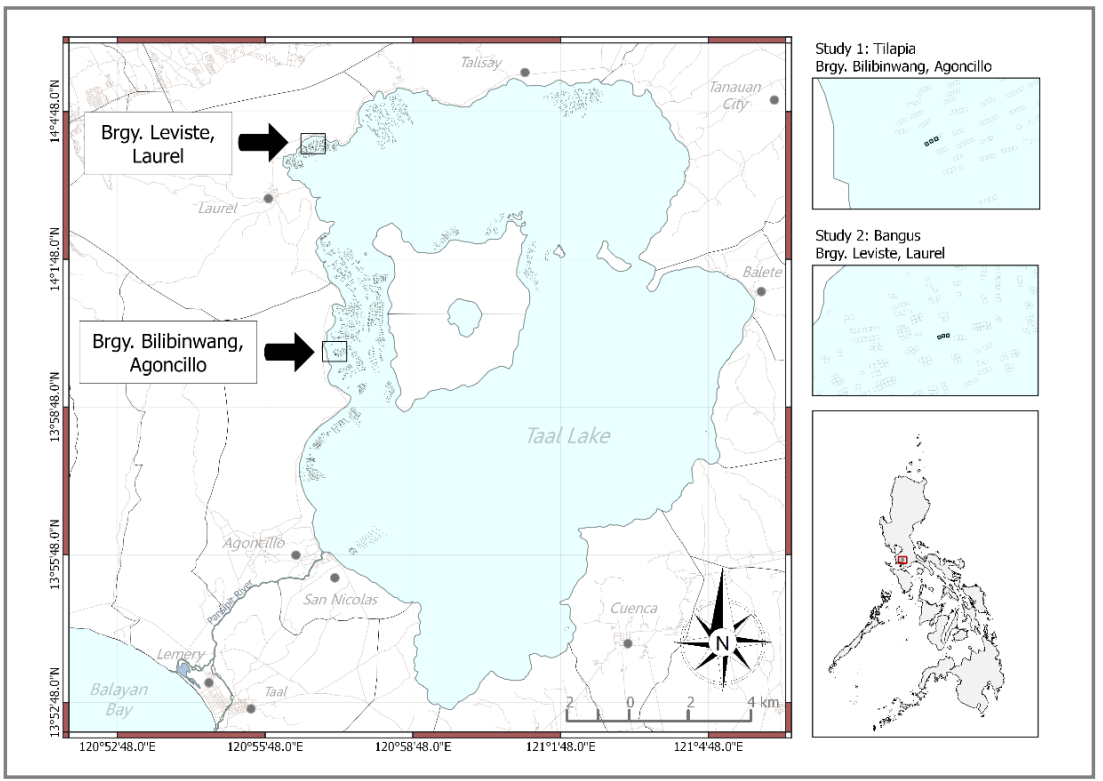

Figure 1. Map showing the experimental site for the tilapia (Oreochromis niloticus) and the milkfish (Chanos chanos) study. such type of feeds is more appropriate to sustain fish production and minimize contribution to water quality degradation (Johnsen and Wansvik, 1991). Extruded feeds occur in floating, slow-sinking, and sinking feeds. Each type of extruded feeds is effective for specific species of fish depending on their feeding habits (Xie et al. 2018). At present, the majority of cage farmers in Taal Lake are using sinking and slowsinking feeds while the extruded floating feed is a relatively recent introduction in cage aquaculture in the area. Although the use of extruded floating feeds is known to perform better in land-based farms, there has been some hesitation on its application in cages for various reasons such as broken sizes in harvested fish, wastage of feeds due to strong waves, and feeds cost. Studies on extruded floating feeds in Taal Lake are lacking and as such, comparative evaluation of extruded floating and non-floating feed types commercially available for $O$. niloticus and C. chanos cage aquaculture is therefore needed to supplement the hypothesis on the relative efficiency of extruded floating feeds over the commonly used non-floating feeds.

This study was conducted to evaluate the growth performance and cost efficiency of extruded floating, extruded slow-sinking, and pressed sinking feeds for O. niloticus and C. chanos reared in net cages and to serve as baseline information for the policy implementation on the use of extruded floating feeds in Taal Lake. The results of the study may also be useful to policy management regulators of other inland waters in the country, as well as in other parts of the world.

\section{MATERIA LS AND METHODS}

The study is composed of two substudies: Study 1 for tilapia (Oreochromis niloticus) and Study 2 for milkfish (Chanos chanos). Each study was conducted separately in two experimental sites located in cage aquaculture zones in Taal Lake, Batangas, specifically Brgy. Bilibinwang, Agoncillo, Batangas for the tilapia study and Brgy. Leviste, Laurel, 
Batangas for the milkfish study (Figure 1). In the tilapia Study, O. niloticus was reared as single species in the experimental cages. Similarly, C. chanos was reared in monoculture in the Milkfish Study experimental site. The experimental period was eight months for $O$. niloticus and ten months for C. chanos from May 2016 to March 2017 upon reaching a marketable size of 250$350 \mathrm{~g}$ for tilapia and 300-400 $\mathrm{g}$ for milkfish. This study is a collaborative project between National Fisheries Research and Development Institute (NFRDI), Department of Environment and Natural ResourcesProtected Areas Superintendent (DENR-PASu), and Bureau of Fisheries and Aquatic Resources Region 4A (BFAR 4A).

\subsection{Experimental design}

The experiment was conducted in a randomized complete block design with three replications (Figure 2). Three feed types were compared: (1) extruded floating feed; (2) extruded slow-sinking feed; and (3) pressed sinking feed; all of which were manufactured and procured from one commercial aquaculture feed company, Santeh Feeds. Each of the three modules represented one blockreplications while each of the three cage nets in the module served as the experimental units or treatments. Each of the three feed types was assigned randomly to the three cage nets in one module. All feed types were represented in each of the block modules.
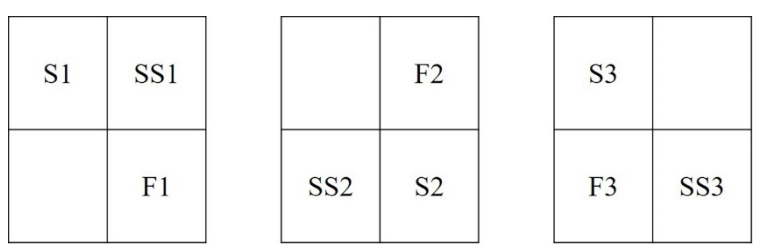

Figure 2. Experimental set up of feeding experiment for O. niloticus and C. chanos study.

In each of the sub-studies, nine units of floating type bamboo-framed cages measuring $4 \mathrm{~m}$ x $4 \mathrm{~m}$ were constructed and installed with net cages made of polyethylene net measuring $4 \mathrm{~m} \mathrm{x} 4 \mathrm{~m} \mathrm{x} 5$ $\mathrm{m}$ (depth). Cages were situated at about $500 \mathrm{~m}$ from the lakeshore with a depth of 12-15 m. The nine cages were divided into three modules with each module having three cages constructed adjacent to each other. Each module was installed $10 \mathrm{~m}$ apart and moored to the bottom of the lake by sandbags supported by polyethylene rope no. 10 .

In the tilapia study experimental site, a total of 36,000 O. niloticus size 14 fingerlings BFAR Strain with a mean weight of $1.7 \pm 0.17 \mathrm{~g}$ (mean length of $4.9 \pm 0.10 \mathrm{~cm}$ ) procured from a private hatchery in Binangonan, Rizal were stocked randomly into the nine cage nets at an equal stocking density of 50 fish $\bullet \mathrm{m}^{-3}$ (4,000 fingerlings per cage net). In the milkfish study experimental site, a total of 10,080 C. chanos fingerlings with a mean weight of $9.27 \pm 1.21 \mathrm{~g}$ (mean length of $8.63 \pm 0.42 \mathrm{~cm}$ ) purchased from a private nursery farm near the experimental site in Brgy. Leviste, Laurel, Batangas were equally distributed among nine cage nets at a density of 14 fish $\bullet \mathrm{m}^{-3}(1,120$ fish per cage net).

\subsection{Feeding of fish}

Fish were fed two times a day at 8:00 AM and 3:00 $\mathrm{PM}$ at a pre-determined feeding rate which ranged from $3-5 \%$ body weight depending on the size of the fish. For each feed type, three feed sizes were utilized, namely starter, grower, and finisher, which were used based on the fish size at rearing period. The actual amount of feeds consumed per feeding period were recorded for the computation of the feed conversion ratio. Net cages were regularly cleaned and scrubbed to prevent fouling of nets and to provide good water circulation. Bamboo raft cage and cage nets were regularly monitored for any damages and immediately repaired when needed. Replacement of cage nets was done every 2-3 months, with each replacement net having larger mesh size (B-net PE net, size 17 PE net, size 14 PE net, and size 10 PE net).

\subsection{Data collection}

Growth performance. Growth evaluation of the fish was conducted every month by collecting 30 random samples from each cage net replicates to determine the growth performance. Weight (in grams) and standard length (in $\mathrm{cm}$ ) of individual fish were measured. The weight gain, absolute growth, and specific growth rate were computed following the formula:

Weight gain $(g)=$

Absolute growth $($ g/day $)=$

Specific growth rate $=$
Final weight - Initial weight

Final weight - Initial weight / no. rearing days

(ln final weight - $\ln$ initial weight) * 100/ no. rearing days (\%/day) 
Survival, Biomass Harvested and Size Distribution. At the end of the experiment, all fishes were harvested from each cage net treatment replicate and weighed. Tilapia were harvested on April 6-10, 2017 and milkfish on April 1-5, 2017. Harvested fish were individually classified according to size by contracted harvester-buyer and bulk weighed by size class. The total weight of fish harvested per size class per feed treatment was recorded for the determination of size distribution harvested fish, expressed in percentage composition of fish per size class per feed treatment. From each of the size class, a random sample of 30 fishes was collected and measured individually to determine the mean weight and length of each size class. The total number of harvested fish, survival rate, and biomass harvested were computed based on the formula:

Actual no. of fish harvested $=($ Total weight of harvested fish at Size A/Mean weight of Size A) + (Total weight of harvested fish at Size B/Mean weight of Size B) + .. + (Total weight of harvested fish at Size E/Mean weight of Size E)

Survival rate $=$ No. of fish harvested/Initial no. fish stocked $\mathrm{x} 100$

Biomass harvested $=$ total weight harvested from 3 cage nets of each feed treatment / 3 cage nets

Feed Conversion Ratio and Feeds consumed. At the end of the experiment, the feed conversion ratio and total feeds consumed were computed as follows:

Feed conversion ratio $=$ Total feeds consumed $/$ Total volume of fish harvested

Total feeds consumed $=$ Total recorded feed consumption per feed treatment

Cost analysis. A simple cost analysis of the three feed treatments was done to assess the cost efficiency of the feed types used in the feeding experiment. The computations for the cost analysis were as follows:

Fixed cost $=$ depreciated cost cage + depreciated cost nets

Operating cost $=$ fingerling cost + feed cost $\_$repair \& maintenance cost + miscellaneous cost
Total cost $=$ fixed cost + operating cost

Sales = Biomass harvest $\mathrm{x}$ market price of fish

Net income $=$ Sales - total cost

Proximate analysis. Proximate nutrient analysis was conducted for both feeds and fish. About $100 \mathrm{~g}$ sample of each feed type at the start of the experiment and $100 \mathrm{~g}$ fish harvested after the experiment was sent to NFRDI Integrated Laboratory, Quezon City for proximate analysis of crude protein, crude fat, ash, and moisture and to SGS Laboratory, Makati City for crude fiber. Both laboratories used the standard method for proximate nutrient analysis (AOAC 1990).

Water Quality. Dissolved oxygen, temperature, and $\mathrm{pH}$ were monitored daily at 9:00 AM and 4:00 PM. Dissolved oxygen and temperature were measured using YSI Pro 20 portable DO meter and $\mathrm{pH}$ was monitored using Eutech Instruments $\mathrm{pH}$ 700. Ammonia, nitrate, and nitrite were monitored once a week using LaMotte Smart 3 colorimeter and total phosphorus was measured using Shimadzu UV Spectrophotometer UV-1800.

\subsection{Statistical Analysis}

Results were presented as means \pm standard error of the mean (SEM). Levene's test (F-max test) was used to test the homogeneity of variance. After confirming homogeneity of variances, analysis of variance (ANOVA) was employed using a univariate general linear model to determine significant differences among treatment effects. Tukey HSD and Scheffe were used to determine specific treatment mean differences. Percentage data were arcsinetransformed prior to ANOVA. Statistical significance was compared at the $5 \%$ probability level. All computations and analysis were carried out using the SPSS version 20.

\section{RES ULT S}

The results presented in this study are consolidated data from the two experimental sites of the two sub-studies conducted.

3.1 Growth performance

The average increase in weight of tilapia (Oreochromis niloticus) at periodic sampling during 


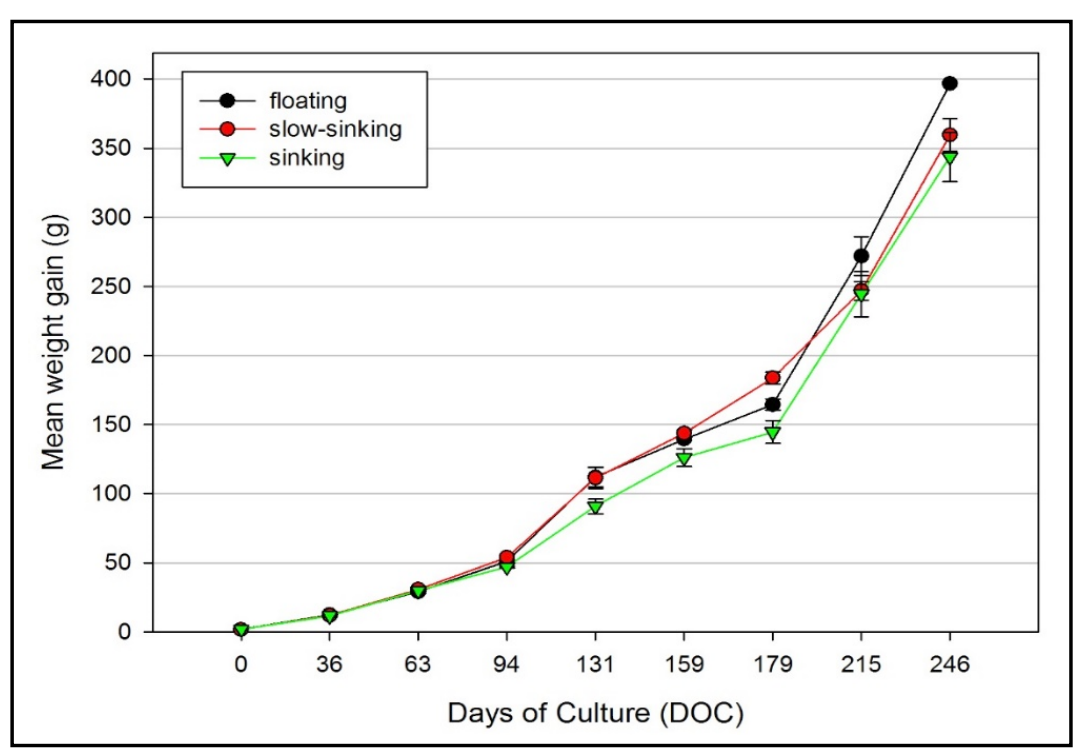

Figure 3. Mean body weight of tilapia (g) fed floating, slow-sinking, and sinking feeds during the 246 days of culture (DOC).

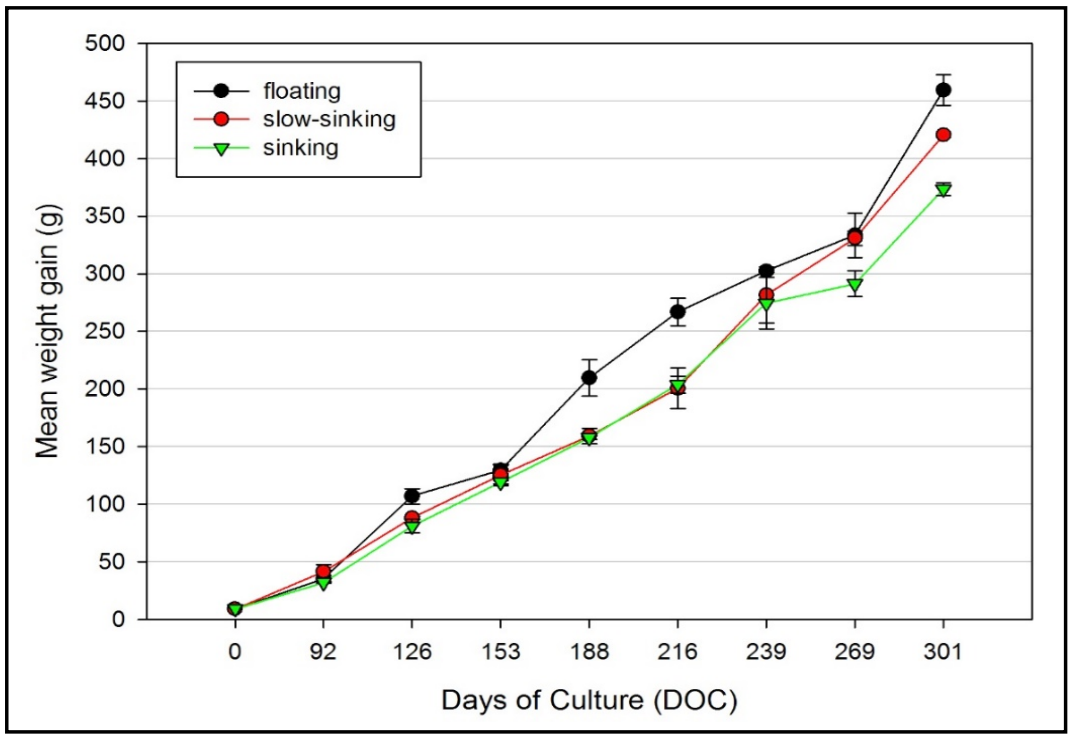

Figure 4. Mean body weight of milkfish (g) fed floating, slow-sinking, and sinking feeds after 301 days of culture (DOC) rearing period, $O$. niloticus had a mean weight gain of $112.03 \pm 7.17 \mathrm{~g}$ in extruded floating feed treatment, $111.25 \pm 7.69 \mathrm{~g}$ in slowsinking feed, and $90.77 \pm 5.40$ $\mathrm{g}$ in sinking feed treatment with no statistical difference between treatments $(\mathrm{P}>0.05)$. Figure 4 shows the average increase in weight of milkfish C. chanos during the study. After 301 days of culture, the final mean weight gain of $C$. chanos fed extruded floating, slow-sinking, and sinking feed type was $459.23 \pm 13.48$ g, $420.53 \pm 1.60 \mathrm{~g}$, and $373.46 \pm 5.41$ g, respectively. Mean weight gain was significantly different among feed treatments $(\mathrm{P}<0.05)$ with extruded floating and slow-sinking feeds attaining significantly higher mean weight gain than sinking feeds. Mean weight gain was not statistically different between C. chanos fed extruded floating and slow-sinking feeds. At four months rearing period, mean weight gain was $106.88 \pm 6.67 \mathrm{~g}$ in extruded floating, $88.05 \pm 1.52 \mathrm{~g}$ in slow-sinking, and $81.00 \pm 5.90$ $\mathrm{g}$ in sinking feed treatment, with extruded floating feeds having significantly higher weight gain than the other two treatments $(\mathrm{P}<0.05)$.

In both $O$. niloticus and the study is presented in Figure 3. Final mean weight gain after 246 days of culture was $396.63 \pm 1.84 \mathrm{~g}$, $359.57 \pm 11.58 \mathrm{~g}$, and $343.60 \pm 17.91 \mathrm{~g}$ for extruded floating, slow-sinking, and sinking feeds, respectively. Analysis of variance showed a significant difference in mean weight gain $(\mathrm{P}<0.05)$ among feed treatments. Mean weight gain was significantly higher in $O$. niloticus fed extruded floating feed than sinking feeds. No significant difference in mean weight gain was detected between $O$. niloticus fed extruded floating and slow-sinking feeds nor between slow-sinking feeds and sinking feed treatments. At four months
C. chanos studies, feed treatments showed significant effects $(\mathrm{P}<0.05)$ on the mean values of absolute growth and specific growth rate (Figure 5). In O. niloticus study, absolute growth and specific growth rate were higher in extruded floating feed treatment $(1.61 \pm 0.007$ g/day and $2.22 \pm 0.002 \% /$ day) than the sinking feed treatment $(1.40 \pm 0.073 \mathrm{~g} /$ day and $2.16 \pm 0.021 \% /$ day $)$. Growth in slow-sinking feed treatment $(1.46 \pm 0.047 \mathrm{~g} /$ day and $2.18 \pm 0.01 \%$ /day) did not differ significantly from extruded floating feed and sinking feed treatments. For C. chanos study, absolute growth and specific growth rate was statistically higher $(\mathrm{P}>0.05)$ 


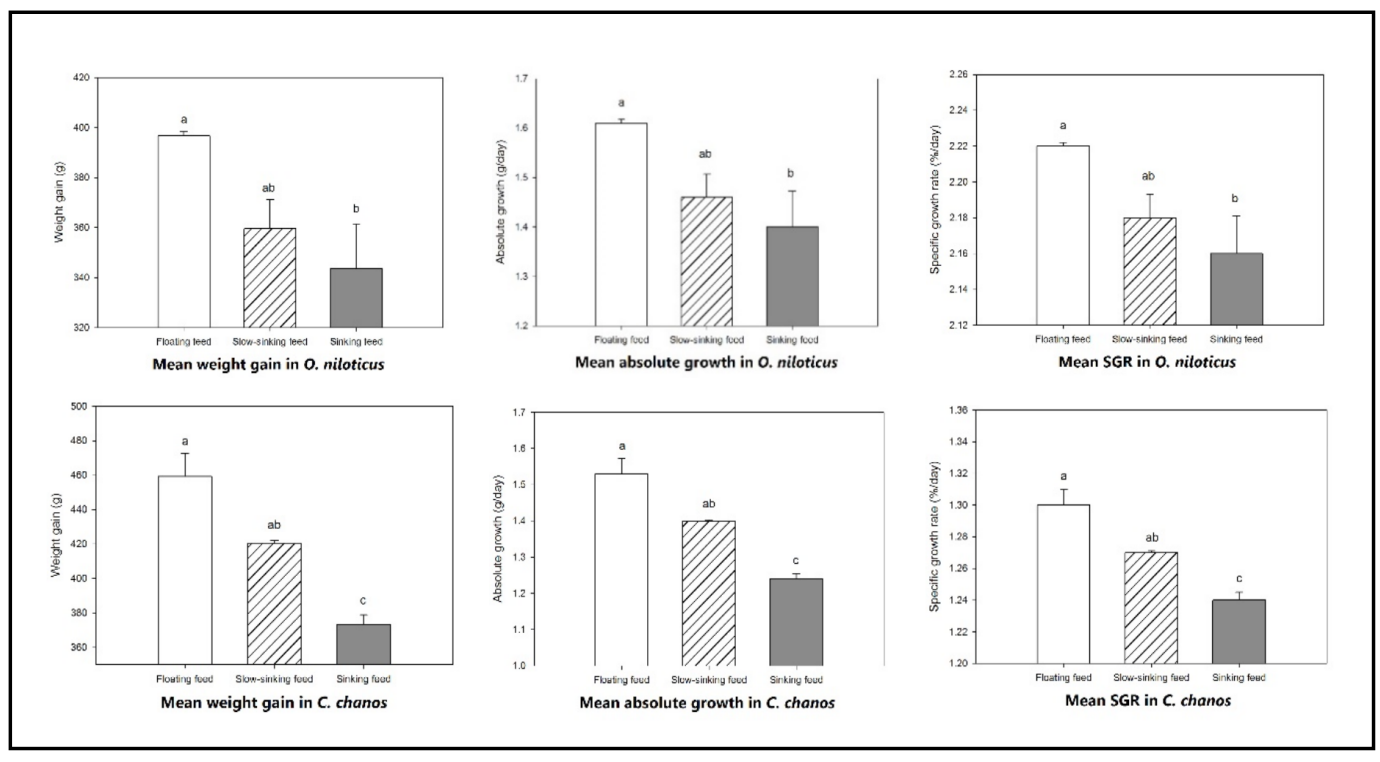

Figure 5. Mean $( \pm$ SEM) weight gain, absolute growth, and specific growth rate of O. niloticus and C. chanos fed extruded floating, slow-sinking, and sinking feeds

in extruded floating feed type $(1.53 \pm 0.043 \mathrm{~g} /$ day and $1.30 \pm 0.01 \% /$ day) and slow-sinking feed treatment $(1.40 \pm 0.003 \mathrm{~g} /$ day and $1.27 \pm 0.001 \% /$ day $)$ than sinking feed type $(1.24 \pm 0.015 \mathrm{~g} /$ day and $1.24 \pm 0.005 \% /$ day $)$. Growth was not significantly different between extruded floating treatment and slow-sinking feed treatment $(\mathrm{P}>0.05)$.

3.2 Percentage Survival, Biomass Harvested and Size Distribution at Harvest

Statistical analysis showed no significant difference in survival rate $(\mathrm{P}>0.05)$ in both $O$. niloticus and $C$. chanos studies (Table 1). The survival rate in $O$. niloticus study ranged from $38.77 \pm 2.8 \%$ to $42.25 \pm 1.41 \%$ and $77.78 \pm 3.05 \%$ to $81.97 \pm 3.92 \%$ in $C$. chanos study. Highest survival rate was achieved by $O$. niloticus fed extruded feeds and C. chanos fed slowsinking feeds. Lowest percentage survival was attained by sinking feed treatment in both species. Gradual mortalities were recorded in O. niloticus experimental fish during the study. The affected fish exhibited inappetence for 1-2 weeks and eventually died with a very thin body and exhibited swirling swimming behavior. Mortalities in both O. niloticus and C. chanos were also noted during low levels of dissolved oxygen levels in the experimental site.

While the percentage survival did not differ between feed treatments, the results of total harvest of experimental fish after the study period (Table 1) showed significant difference in the biomass harvest
$(\mathrm{P}<0.05)$ between feed treatments in both $O$. niloticus and $C$. chanos studies as a result of the significant difference in the mean weight gain. Biomass harvested was highest in O. niloticus fed extruded floating feeds at $991.33 \pm 29.36 \mathrm{~kg}$ which was significantly higher than O. niloticus fed slow-sinking and O. niloticus fed sinking feeds with $828.00 \pm 16.92 \mathrm{~kg}$ and $731.00 \pm 20.26$ $\mathrm{kg}$, respectively. However, no significant difference was detected in biomass harvested between slowsinking and sinking feed treatments. For C. chanos, biomass harvest in extruded floating feed treatment $(702.17 \pm 13.18 \mathrm{~kg})$ was significantly higher than sinking feed treatment $(572.33 \pm 14.19 \mathrm{~kg})$ but was not statistically different from slow-sinking feed treatment $(678.17 \pm 30.31 \mathrm{~kg})$. Biomass harvest did not differ significantly between slow-sinking and sinking feed treatments.

Moreover, results of the size distribution at harvest showed significantly higher percentage $(\mathrm{P}<0.05)$ of good-sized fish $(250 \mathrm{~g}$ and larger in $O$. niloticus and $300 \mathrm{~g}$ and larger in C. chanos) in extruded floating feed treatments than the other two feed types for both O. niloticus study (Table 2a) and C. chanos study (Table 2b). Sinking feed treatment attained the lowest percentage of good-sized fish in both species. Mean percentage of good sized harvested fish for extruded floating, slow-sinking, and sinking feed treatment was $84.01 \pm 2.51 \% \%, 66.78 \pm 6.67 \%$, and $55.41 \pm 7.30 \%$, respectively for O. niloticus, and $84.46 \pm 5.58 \%, \quad 72.80 \pm 0.80 \%$, and $64.12 \pm 9.66 \%$, respectively for C. chanos. 
Table 1. Mean values $( \pm$ SEM) of survival rate and biomass harvested of tilapia and milkfish fed three feed types reared in experimental cages.

\begin{tabular}{|c|c|c|}
\hline Treatment & Survival Rate (\%) & Biomass harvested (kg) \\
\hline \multicolumn{3}{|l|}{ A. Tilapia } \\
\hline \begin{tabular}{l|l} 
Floating feed \\
\end{tabular} & $45.25 \pm 1.41 \mathrm{a}$ & $991.33 \pm 29.36 a$ \\
\hline Slow-sinking feed & $41.80 \pm 2.01 \mathrm{a}$ & $828.00 \pm 16.92 b$ \\
\hline Sinking feed & $38.77 \pm 2.82 \mathrm{a}$ & $731.00 \pm 20.26 b$ \\
\hline \multicolumn{3}{|l|}{ B. Milkfish } \\
\hline \begin{tabular}{l|l} 
Floating feed \\
\end{tabular} & $77.92 \pm 1.41 \mathrm{a}$ & $702.17 \pm 22.4613 .18 \mathrm{a}$ \\
\hline Slow-sinking feed & $81.97 \pm 3.92 \mathrm{a}$ & $678.17 \pm 30.31 \mathrm{ab}$ \\
\hline Sinking feed & $77.78 \pm 3.05 a$ & $572.33 \pm 14.19 b$ \\
\hline
\end{tabular}

${ }^{\star}$ In a column, means followed by a common letter are not significantly different at $5 \%$ level by Tukey HSD and Scheffe; \pm indicates standard error of the mean (SEM)

Table 2a. Size distribution of harvested tilapia fed three feed types after 246 days of culture.

\begin{tabular}{|l|c|c|c|c|c|c|}
\hline \multicolumn{1}{|c|}{ Treatment } & $\begin{array}{c}\text { Total Good Size, } \\
\text { medium to jumbo } \\
(\mathbf{\%})\end{array}$ & $\begin{array}{c}\text { Jumbo } \\
\mathbf{> 5 0 0 g}\end{array}$ & $\begin{array}{c}\text { Big } \\
\mathbf{3 5 0 - 5 0 0 g}\end{array}$ & $\begin{array}{c}\text { Medium } \\
\mathbf{2 5 0 - 3 5 0 g}\end{array}$ & $\begin{array}{c}\text { Small } \\
\mathbf{2 0 0 - 2 5 0 g}\end{array}$ & $\begin{array}{c}\text { Reject } \\
<\mathbf{2 0 0 g}\end{array}$ \\
\hline Floating feeds & $84.01 \pm 2.51 \mathrm{a}$ & 22.40 & 23.80 & 37.80 & 12.15 & 3.84 \\
\hline Slow-sinking feeds & $66.78 \pm 6.67 \mathrm{~b}$ & 8.72 & 26.97 & 31.09 & 26.32 & 6.91 \\
\hline Sinking feed & $55.41 \pm 7.30 \mathrm{c}$ & 6.32 & 17.80 & 31.28 & 38.10 & 6.49 \\
\hline
\end{tabular}

Table 2b. Size distribution of harvested milkfish fed three feed types after 246 days of culture.

\begin{tabular}{|c|c|c|c|c|c|c|c|}
\hline Treatment & $\begin{array}{l}\text { Total Good } \\
\text { Size, } 3 / 1 \text { to } \\
\text { jumbo (\%) }\end{array}$ & $\begin{array}{c}\text { Jumbo } \\
(\%) \\
>500 \mathrm{~g}\end{array}$ & $\begin{array}{c}2 / 1 \\
(\%) \\
450-500 \mathrm{~g}\end{array}$ & $\begin{array}{c}5 / 2 \\
(\%) \\
400-450 \mathrm{~g}\end{array}$ & $\begin{array}{c}3 / 1 \\
(\%) \\
350-400 \mathrm{~g}\end{array}$ & $\begin{array}{c}4 / 1 \\
(\%) \\
250-300 \mathrm{~g}\end{array}$ & $\begin{array}{c}5 / 1 \\
(\%) \\
200-250 \mathrm{~g}\end{array}$ \\
\hline Floating feed & $84.46 \pm 5.58 \mathrm{a}$ & 4.79 & 20.01 & 29.55 & 30.11 & 14.10 & 1.44 \\
\hline Slow-sinking feed & $72.80 \pm 0.80 \mathrm{~b}$ & - & 4.58 & 32.75 & 35.47 & 25.22 & 1.98 \\
\hline Sinking feed & $64.12 \pm 9.66 c$ & - & 8.31 & 14.37 & 41.44 & 30.21 & 5.67 \\
\hline
\end{tabular}

\subsection{Feed Conversion Ratio and Feeds Consumed}

Analysis of variance indicated significant differences in feed conversion ratio $(\mathrm{P}<0.05)$ in both $O$. niloticus and C. chanos studies (Table 3). Feed conversion ratio ranged from $1.39 \pm 0.03$ to $1.99 \pm 0.07$ in O. niloticus and $1.79 \pm 0.04$ to $2.41 \pm 0.11$ in C. chanos. Lowest FCR was achieved by extruded floating feed treatments for both $O$. niloticus and $C$. chanos while highest in sinking feed treatment. In both species, FCR of fish fed extruded floating feed was significantly lower than fish fed sinking feed. No significant difference was detected between FCR of O. niloticus fed slow-sinking and sinking feed, between C. chanos fed extruded floating and slow-sinking feeds, and between C. chanos fed slow-sinking and sinking feeds. Mean weight of total feeds consumed by experimental fish during the study period (Table 3) was not statistically different between feed treatments $(\mathrm{P}>0.05)$ in $O$. niloticus study which ranged from $1375.85 \pm 6.29 \mathrm{~kg}$ to $1454.75 \pm 113.86 \mathrm{~kg}$. However, a significant difference was detected in the mean weight feed consumption of $C$. chanos study $(\mathrm{P}<0.05)$. C. chanos fed extruded floating feed consumed significantly higher mean weight of feed consumed $(1256.01 \pm 5.06 \mathrm{~kg})$ than C. chanos fed slow-sinking $(1380.40 \pm 4.89 \mathrm{~kg})$ and sinking feeds $(1401.90 \pm 6.12$ $\mathrm{kg}$ ). Feed consumption between slow-sinking and sinking feed treatments was not statistically different. 
The Philippine Journal of Fisheries 25(2): 41-56

Table 3. Mean values $( \pm$ SEM) of feeds consumed and feed conversion ratio of tilapia and milkfish fed three feed types reared in experimental cages.

\begin{tabular}{|c|c|c|}
\hline Treatment & Feeds consumed $(\mathrm{kg})$ & Feed conversion ratio \\
\hline \multicolumn{3}{|l|}{ A. Tilapia } \\
\hline \begin{tabular}{l|l} 
Floating feed \\
\end{tabular} & $1375.85 \pm 6.29 a$ & $1.39 \pm 0.03 c$ \\
\hline Slow-sinking feed & $1371.42 \pm 79.8 \mathrm{a}$ & $1.66 \pm 0.07 \mathrm{ab}$ \\
\hline Sinking feed & $1454.75 \pm 113.86 a$ & $1.99 \pm 0.11 \mathrm{a}$ \\
\hline \multicolumn{3}{|l|}{ B. Milkfish } \\
\hline \begin{tabular}{l|l} 
Floating feed \\
\end{tabular} & $1256.01 \pm 5.06 \mathrm{~b}$ & $1.79 \pm 0.04 \mathrm{~b}$ \\
\hline Slow-sinking feed & $1380.40 \pm 4.89 \mathrm{a}$ & $2.03 \pm 0.01 \mathrm{ab}$ \\
\hline Sinking feed & $1401.90 \pm 6.12 \mathrm{a}$ & $2.41 \pm 0.07 \mathrm{a}$ \\
\hline
\end{tabular}

${ }^{*}$ In a column, means followed by a common letter are not significantly different at $5 \%$ level by Tukey HSD and Scheffe; \pm indicates standard error of the mean (SEM)

Table 4a. Cost analysis of tilapia cage farming comparing floating, slow-sinking, and sinking feeds at 8 months culture period.

\begin{tabular}{|c|c|c|c|}
\hline & Floating feeds & Slow-sinking feeds & Sinking feeds \\
\hline \multicolumn{4}{|l|}{ A. Fixed cost } \\
\hline \begin{tabular}{l|l} 
& Cage (depreciated) \\
\end{tabular} & 12,000 & 12,000 & 12,000 \\
\hline Nets (depreciated) & 9,000 & 9,000 & 9,000 \\
\hline \multicolumn{4}{|l|}{ B. Operating cost } \\
\hline \begin{tabular}{l|l} 
& Fingerlings \\
\end{tabular} & 22,500 & 22,500 & 22,500 \\
\hline Feeds & $402,408.70$ & $399,531.55$ & $399,263.15$ \\
\hline Labor & 28,000 & 28,000 & 28,000 \\
\hline Repair \& maint. & 5,000 & 5,000 & 5,000 \\
\hline \begin{tabular}{l|l} 
& Miscellaneous \\
\end{tabular} & 10,000 & 10,000 & 10,000 \\
\hline C. Total cost & $488,980.70$ & $486,031.55$ & $485,763.15$ \\
\hline D. Sales & $703,356.25$ & $593,867.70$ & $529,586.88$ \\
\hline E. Net income & $214,447.60$ & $107,836.00$ & $43,823.73$ \\
\hline
\end{tabular}

Note: All costs were calculated for a $10 \mathrm{~m}$ x $10 \mathrm{~m}$ x $10 \mathrm{~m}$ standard sized cage allowed in Taal Lake using data generated from the study

3.4 Cost and Returns, Cost Efficiency and Decreased Volume of Feeds Used

Simple cost and returns for O. niloticus cage farming were calculated for a $10 \mathrm{~m}$ x $10 \mathrm{~m}$ x $10 \mathrm{~m}$ standard size net cage allowed in Taal Lake using data generated from the study after 246 days ( 8 months) as shown in Table 4a. Cost analysis showed that the net income is highest in the cage using floating feeds with PHP 214,447.60 (USD 4,288.95) followed by slowsinking feeds with PHP 107,836.00 (USD 2,156.72) and lowest in sinking feeds with PHP 43,823.73 (USD 876.47). At about four months rearing period (131 days), cost analysis showed that expected volume of harvest and sales of fish (Table $4 \mathrm{~b}$ ) is still low. Net returns in extruded floating feed treatment, slowsinking, and sinking feed treatment was PhP 6,021.48,
-PHP 11,442.72 and -PHP 3,302.66, respectively. Mean weight of fish at this stage is less than $150 \mathrm{~g}$. Harvesting of fish at this period is not yet economically viable.

The estimated total required feeds and feed cost for each feed type for a regular sized $10 \mathrm{~m} \times 10 \mathrm{~m}$ $\mathrm{x} 10 \mathrm{~m}$ cage is shown in Table 5. Based on the estimate, to reach the targeted yield of 5 tons of tilapia a total of $10,000 \mathrm{~kg}$ feeds would be needed if conventional sinking feeds will be used. At the same biomass at harvest, $7,000 \mathrm{~kg}$ is needed when floating feeds is used and 8,500 kg feeds when slow-sinking feeds are used. A decrease in feed cost from PHP 314,500.00 to PHP 221,900.00 (USD 6,290 to USD 4,438) would be achieved when floating feeds is used instead of sinking feeds. A decrease in feed cost by PHP 92,600.00 (USD 1,852 ) will be attained, thereby increasing the income by $29.44 \%$. Moreover, this will lessen the number of 
Table $4 \mathrm{~b}$. Cost analysis of tilapia cage farming comparing floating, slow-sinking, and sinking feeds at 4 months culture period.

\begin{tabular}{|c|c|c|c|}
\hline & Floating feeds & Slow-sinking feeds & Sinking feeds \\
\hline \multicolumn{4}{|l|}{ A. Fixed cost } \\
\hline \begin{tabular}{l|l} 
& Cage (depreciated) \\
\end{tabular} & 12,000 & 12,000 & 12,000 \\
\hline Nets (depreciated) & 9,000 & 9,000 & 9,000 \\
\hline \multicolumn{4}{|l|}{ B. Operating cost } \\
\hline \begin{tabular}{l|l} 
& Fingerlings \\
\end{tabular} & 22,500 & 22,500 & 22,500 \\
\hline Feeds & $35,103.90$ & $42,750.60$ & $32,332.14$ \\
\hline Labor & 16,000 & 16,000 & 16,000 \\
\hline Repair \& paint & 5,000 & 5,000 & 5,000 \\
\hline Miscellaneous & 5,000 & 5,000 & 5,000 \\
\hline C. Total cost & 104.603 .90 & $112,250.60$ & $85,832.14$ \\
\hline D. Sales & $110,625.38$ & $100,807.88$ & $82,529.48$ \\
\hline E. Net income & $6,021.48$ & $(11,442.72)$ & $(3,302.66)$ \\
\hline
\end{tabular}

Note: All costs were calculated for a $10 \mathrm{~m}$ x $10 \mathrm{~m}$ x $10 \mathrm{~m}$ standard sized cage allowed in Taal Lake using data generated from the study

Table 5. Estimated feed requirements and feed cost in rearing tilapia and milkfish using the three feed types with values of FCR and feed price from the study as basis for computations

\begin{tabular}{|c|c|c|c|c|c|}
\hline Treatment & $\begin{array}{l}\text { Target Biomass } \\
\text { at harvest }(\mathrm{kg})\end{array}$ & $\begin{array}{c}\text { FCR based } \\
\text { on study }\end{array}$ & $\begin{array}{c}\text { Total feeds } \\
\text { requirements }(\mathrm{kg})\end{array}$ & $\begin{array}{l}\text { Price of feeds } \\
\text { per kg }(\mathrm{PhP})\end{array}$ & $\begin{array}{l}\text { Total Feeds } \\
\text { Cost (PhP) }\end{array}$ \\
\hline \multicolumn{6}{|l|}{ A. Tilapia } \\
\hline \begin{tabular}{l|l} 
& Floating feed \\
\end{tabular} & 5,000 & 1.4 & 7,000 & 31.70 & $221,900.00$ \\
\hline Slow-sinking feed & 5,000 & 1.7 & 8,500 & 31.45 & $267,325.00$ \\
\hline \begin{tabular}{l|l} 
& Sinking feed \\
\end{tabular} & 5,000 & 2.0 & 10,000 & 31.45 & $314,500.00$ \\
\hline \multicolumn{6}{|l|}{ B. Milkfish } \\
\hline \begin{tabular}{l|l} 
& Floating feed \\
\end{tabular} & 5,000 & 1.8 & 9,000 & 31.70 & $285,300.00$ \\
\hline Slow-sinking feed & 5,000 & 2.03 & 10,450 & 31.03 & $324,263.50$ \\
\hline Sinking feed & 5,000 & 2.41 & 11,200 & 31.03 & $347,536.00$ \\
\hline
\end{tabular}

Note: Feed amount and feed cost were calculated for a $10 \mathrm{~m}$ x $10 \mathrm{~m}$ x $10 \mathrm{~m}$ standard sized cage allowed in Taal Lake using data generated from the study

feeds used by $30 \%$. This is mainly due to the relative efficiency of floating feeds as feeds for tilapia as reflected by the lower FCR.

Similarly, for C. chanos, the use of floating feeds entailed lesser volume of feed used and lower feed cost making it more efficient compared to slowsinking and sinking feeds. From a total volume of $11,200 \mathrm{~kg}$ feeds for sinking feed type with a value of PHP 347,536.00 (USD 6,950.72), the volume of feeds decreased to $9,000 \mathrm{~kg}$ with the use of floating feeds with a value of PHP 285,300.00 (USD 5,706). This translates to a decrease in the use of feeds by $2,200 \mathrm{~kg}$ feeds (19.64\%) and lower feed cost by PHP 62,236.00 (USD 1,244.72) or $17.91 \%$.

\subsection{Proximate Analysis}

Proximate analysis of the three feed types used for O. niloticus and C. chanos studies is presented in Table 6. Results of ANOVA showed no significant difference $(P>0.05)$ in the mean crude protein and crude fiber between feed types in both $O$. niloticus and C. chanos studies. Moisture content was also not statistically different among different $C$. chanos feed types $(\mathrm{P}>0.05)$. However, significant differences were detected in the mean crude fat and ash of the three feed types in the two species $(\mathrm{P}<0.05)$ and in the mean percentage moisture of $O$. niloticus $(\mathrm{P}<0.05)$. In $O$. niloticus feed types, slow-sinking feed had the highest 
Table 6. Proximate analysis $( \pm$ SEM) of floating, slow sinking, and sinking tilapia and milkfish feeds compared in the study

\begin{tabular}{|c|c|c|c|c|c|}
\hline Treatment & Protein (\%) & Fiber (\%) & Fat (\%) & Moisture (\%) & Ash (\%) \\
\hline \multicolumn{6}{|l|}{ A. Tilapia } \\
\hline \begin{tabular}{l|l} 
& Floating feed \\
\end{tabular} & $29.52 \pm 1.29 a$ & 5.21 & $5.02 \pm 0.14 b c$ & $9.50 \pm 0.10 \mathrm{~b}$ & $9.23 \pm 0.03 c$ \\
\hline Slow-sinking feed & $31.81 \pm 0.10 \mathrm{a}$ & 6.19 & $9.20 \pm 0.31 \mathrm{a}$ & $8.17 \pm 0.17 c$ & $10.88 \pm 0.04 a$ \\
\hline \begin{tabular}{l|l} 
& Sinking feed \\
\end{tabular} & $30.90 \pm 0.52 \mathrm{a}$ & 4.49 & $6.22 \pm 0.41 b$ & $10.88 \pm 0.40 \mathrm{a}$ & $10.74 \pm 0.03 \mathrm{ab}$ \\
\hline \multicolumn{6}{|l|}{ B. Milkfish } \\
\hline \begin{tabular}{l|l} 
& Floating feed \\
\end{tabular} & $32.21 \pm 0.08 \mathrm{a}$ & 5.17 & $3.31 \pm 0.07 c$ & $10.85 \pm 2.27 \mathrm{a}$ & $10.11 \pm 0.10 \mathrm{~b}$ \\
\hline Slow-sinking feed & $32.28 \pm 0.14 a$ & 4.82 & $5.49 \pm 0.29 b$ & $8.18 \pm 0.10 \mathrm{a}$ & $10.70 \pm 0.03 a$ \\
\hline Sinking feed & $31.90 \pm 0.10 \mathrm{a}$ & 4.44 & $7.62 \pm 0.23 a$ & $11.33 \pm 0.06 \mathrm{a}$ & $10.04 \pm 0.04 \mathrm{bc}$ \\
\hline
\end{tabular}

*In a column, means followed by a common letter are not significantly different at $5 \%$ level

by Tukey HSD and Scheffe; \pm indicates standard error of the mean (SEM)

Table 7. Proximate analysis $( \pm$ SEM) of harvested tilapia and milkfish fed with floating, slow-sinking, and sinking feeds compared in the study

\begin{tabular}{|c|c|c|c|c|c|}
\hline Treatment & Protein (\%) & Fiber $(\%)$ & Fat $(\%)$ & Moisture (\%) & Ash (\%) \\
\hline \multicolumn{6}{|l|}{ A Oreochromis niloticus } \\
\hline \begin{tabular}{l|l} 
& Floating feed \\
\end{tabular} & $19.47 \pm 0.31 \mathrm{a}$ & $<0.10$ & $0.85 \pm 0.11 b$ & $78.44 \pm 0.062 \mathrm{a}$ & $1.31 \pm 0.03 \mathrm{a}$ \\
\hline Slow-sinking feed & $19.29 \pm 0.81 \mathrm{a}$ & $<0.10$ & $0.53 \pm 0.09 c$ & $80.57 \pm 0.58 \mathrm{a}$ & $1.27 \pm 0.05 \mathrm{a}$ \\
\hline Sinking feed & $19.34 \pm 0.22 \mathrm{a}$ & $<0.10$ & $1.30 \pm 0.07 \mathrm{a}$ & $79.32 \pm 0.58 \mathrm{a}$ & $1.19 \pm 0.01 \mathrm{a}$ \\
\hline \multicolumn{6}{|l|}{ B. Chanos chanos } \\
\hline \begin{tabular}{l|l} 
& Floating feed \\
\end{tabular} & $21.93 \pm 0.39 a$ & $<0.10$ & $2.18 \pm 0.32 b$ & $70.96 \pm 0.36 a$ & $1.29 \pm 0.05 \mathrm{a}$ \\
\hline Slow-sinking feed & $22.07 \pm 0.37 \mathrm{a}$ & $<0.10$ & $2.57 \pm 0.30 \mathrm{a}$ & $72.55 \pm 0.34 \mathrm{a}$ & $1.36 \pm 0.03 \mathrm{a}$ \\
\hline Sinking feed & $20.74 \pm 0.44 a$ & $<0.10$ & $1.83 \pm 0.06 \mathrm{bc}$ & $72.11 \pm 0.25 a$ & $1.31 \pm 0.03 \mathrm{a}$ \\
\hline
\end{tabular}

*In a column, means followed by a common letter are not significantly different at $5 \%$ level by Tukey HSD and Scheffe; \pm indicates standard error of the mean (SEM)

mean crude fat and ash while moisture content was highest in sinking feed. For C. chanos feed types, the highest mean percentage fat was noted in sinking feeds and the highest mean percentage ash in slowsinking feeds. Protein content ranged from $29.52 \pm 1.29$ to $31.81 \pm 0.10 \%$ in O. niloticus and $31.90 \pm 0.10$ to $32.28 \pm 0.14 \%$ in C. chanos.

Results of the proximate analysis of fish flesh of harvested $O$. niloticus study and C. chanos study (Table 7) showed that the different feed treatments have significant effect on the body crude fat $(\mathrm{P}<0.05)$ but not on crude protein, crude fiber, ash, and moisture ( $\mathrm{P}>0.05$ ) with $O$. niloticus fed sinking feeds and $C$. chanos fed slow-sinking feeds having significantly higher fat content than fish fed with any other feed types.

\subsection{Water Quality}

Results of statistical analysis of water parameters of experimental cages (Table 8) showed that mean readings of all parameters did not differ significantly between treatments $(\mathrm{P}>0.05)$ in experimental sites in both $O$. niloticus and C. chanos studies. All parameters were within optimum levels except for dissolved oxygen which was less than the $5.0 \mathrm{mg} \cdot \mathrm{li}^{-1}$ optimum. Comparing the experimental cages which lie within the cage aquaculture zone and the open water non-cage area about 200 meters away, mean readings of dissolved oxygen level were significantly higher in the non-cage zone than the cage area $(\mathrm{P}<0.05)$. The non-cage area had mean dissolved oxygen reading of $4.925 \pm 0.020 \mathrm{mg}^{\circ} \mathrm{li}^{-1}$ in $O$. niloticus study area and $4.622 \pm 0.026 \mathrm{mg} \cdot \mathrm{li}^{-1}$ in C. chanos site. Low levels of dissolved oxygen $(<4.0$ $\mathrm{ppm}$ ) were recorded for one to two times in a month in both $O$. niloticus and $C$. chanos cage sites which caused poor appetite and gradual mortality in the experimental fish. DO levels even dropped to below $2.5 \mathrm{mg} \cdot \mathrm{i}^{-1}$ during the month of August. Inappetence and mortalities were recorded during this period. 
Table 8. Mean readings of water parameters in O. niloticus and C. chanos experimental cages.

\begin{tabular}{|c|c|c|c|c|c|c|c|c|}
\hline Parameters & \multicolumn{3}{|c|}{ Oreochromis niloticus cages } & & \multicolumn{3}{|c|}{ Chanos chanos cages } & \\
\hline & Floating & $\begin{array}{l}\text { Slow- } \\
\text { sinking }\end{array}$ & Sinking & $\begin{array}{c}\text { Non-cage } \\
\text { area }\end{array}$ & Floating & $\begin{array}{c}\text { Slow- } \\
\text { sinking }\end{array}$ & Sinking & $\begin{array}{c}\text { Non-cage } \\
\text { area }\end{array}$ \\
\hline $\begin{array}{l}\text { Dissolved } \\
\text { oxygen } \\
(\mathrm{mg} \cdot \mathrm{li}-1)\end{array}$ & $\begin{array}{c}4.069 \\
\pm 0.123 \mathrm{~b}\end{array}$ & $\begin{array}{c}4.019 \\
\pm 0.135 b\end{array}$ & $\begin{array}{r}3.919 \\
\pm 0.167 \mathrm{~b}\end{array}$ & $\begin{array}{c}4.93 \\
\pm 0.020 \mathrm{a}\end{array}$ & $\begin{array}{c}3.523 \\
\pm 0.042 \mathrm{~b}\end{array}$ & $\begin{array}{c}3.57 \\
5 \pm 0.045 b\end{array}$ & $\begin{array}{c}3.544 \\
\pm 0.036 b\end{array}$ & $\begin{array}{c}4.622 \\
\pm 0.026 \mathrm{a}\end{array}$ \\
\hline $\begin{array}{l}\text { Temperature } \\
\text { (oC) }\end{array}$ & $\begin{array}{r}30.40 \\
\pm 0.007 a\end{array}$ & $\begin{array}{r}30.45 \\
\pm 0.014 a\end{array}$ & $\begin{array}{r}30.43 \\
\pm 0.013 a\end{array}$ & $\begin{array}{c}30.31 \\
\pm 0.003 \mathrm{~b}\end{array}$ & $\begin{array}{c}31.18 \\
\pm 0.018 \mathrm{a}\end{array}$ & $\begin{array}{r}31.20 \\
\pm 0.007 \mathrm{a}\end{array}$ & $\begin{array}{c}31.20 \\
\pm 0.007 a\end{array}$ & $\begin{array}{c}31.15 \\
\pm 0.020 \mathrm{a}\end{array}$ \\
\hline $\mathrm{pH}$ & 7.9167 & 7.9167 & 7.9167 & 7.9167 & 7.7667 & 7.7667 & 7.7667 & 7.7667 \\
\hline $\begin{array}{l}\text { Transparency } \\
(\mathrm{cm})\end{array}$ & $\begin{array}{c}1.699 \\
\pm 0.015\end{array}$ & $\begin{array}{c}1.696 \\
\pm 0.009\end{array}$ & $\begin{array}{c}1.781 \\
\pm 0.013\end{array}$ & $\begin{array}{c}1.756 \\
\pm 0.003\end{array}$ & $\begin{array}{c}1.912 \\
\pm 0.013\end{array}$ & $\begin{array}{c}1.909 \\
\pm 0.008\end{array}$ & $\begin{array}{c}1.914 \\
\pm 0.008\end{array}$ & $\begin{array}{c}1.905 \\
\pm 0.002\end{array}$ \\
\hline $\begin{array}{l}\text { Ammonia } \\
(m g \bullet l i-1)\end{array}$ & $\begin{array}{c}3.479 \\
\pm 1.210\end{array}$ & $\begin{array}{c}3.454 \\
\pm 1.140\end{array}$ & $\begin{array}{c}3.512 \\
\pm 1.311\end{array}$ & $\begin{array}{c}3.262 \\
\pm 0.727\end{array}$ & $\begin{array}{r}4.1839 \\
\pm 1.783\end{array}$ & $\begin{array}{l}4.1976 \\
\pm 1.886\end{array}$ & $\begin{array}{r}4.3452 \\
\pm 2.156\end{array}$ & $\begin{array}{l}4.1844 \\
\pm 1.479\end{array}$ \\
\hline $\begin{array}{l}\text { Nitrate } \\
(\mathrm{mg} \bullet \mathrm{li}-1)\end{array}$ & $\begin{array}{l}0.8268 \\
\pm 0.533\end{array}$ & $\begin{array}{l}0.8368 \\
\pm 0.633\end{array}$ & $\begin{array}{l}0.9012 \\
\pm 0.493\end{array}$ & $\begin{array}{l}0.8553 \\
\pm 0.776\end{array}$ & $\begin{array}{l}0.7154 \\
\pm 0.269\end{array}$ & $\begin{array}{l}0.8078 \\
\pm 0.398\end{array}$ & $\begin{array}{l}0.7367 \\
\pm 0.481\end{array}$ & $\begin{array}{l}0.6365 \\
\pm 0.534\end{array}$ \\
\hline $\begin{array}{l}\text { Nitrite } \\
(\mathrm{mg} \bullet \mathrm{li}-1)\end{array}$ & $\begin{array}{l}0.0050 \\
\pm 0.009\end{array}$ & $\begin{array}{c}0.0070 \\
\pm 0.01\end{array}$ & $\begin{array}{l}0.0063 \\
\pm 0.013\end{array}$ & $\begin{array}{l}0.0052 \\
\pm 0.089\end{array}$ & $\begin{array}{l}0.0050 \\
\pm 0.009\end{array}$ & $\begin{array}{l}0.0053 \\
\pm 0.023\end{array}$ & $\begin{array}{l}0.0049 \\
\pm 0.012\end{array}$ & $\begin{array}{l}0.0068 \\
\pm 0.012\end{array}$ \\
\hline $\begin{array}{l}\text { Total Nitrogen } \\
(\mathrm{mg} \cdot \mathrm{li}-1)\end{array}$ & $\begin{array}{l}2.9092 \\
\pm 2.129\end{array}$ & $\begin{array}{l}2.8095 \\
\pm 2.412\end{array}$ & $\begin{array}{l}2.9113 \\
\pm 2.228\end{array}$ & $\begin{array}{r}2.9550 \\
\pm 2.855\end{array}$ & $\begin{array}{l}2.6285 \\
\pm 2.071\end{array}$ & $\begin{array}{l}2.7123 \\
\pm 3.189\end{array}$ & $\begin{array}{l}2.8731 \\
\pm 2.110\end{array}$ & $\begin{array}{l}2.9942 \\
\pm 2.532\end{array}$ \\
\hline $\begin{array}{l}\text { Phosphate } \\
(\mathrm{mg} \cdot \mathrm{li}-1)\end{array}$ & $\begin{array}{r}1.8286 \\
\pm 0.084\end{array}$ & $\begin{array}{c}1.923 \\
\pm 0.094\end{array}$ & $\begin{array}{c}1.789 \\
\pm 0.093\end{array}$ & $\begin{array}{r}1.8283 \\
\pm 0.083\end{array}$ & $\begin{array}{l}1.8643 \\
\pm 0.067\end{array}$ & $\begin{array}{r}1.9645 \\
\pm 0.071\end{array}$ & $\begin{array}{l}1.8761 \\
\pm 0.083\end{array}$ & $\begin{array}{r}1.8442 \\
\pm 0.069\end{array}$ \\
\hline $\begin{array}{l}\text { Hardness } \\
(\mathrm{mg} \cdot \mathrm{li}-1)\end{array}$ & $\begin{array}{r}266.67 \\
\pm 11.55\end{array}$ & $\begin{array}{r}267.86 \\
\pm 10.65\end{array}$ & $\begin{array}{l}271.87 \\
\pm 12.77\end{array}$ & $\begin{array}{c}266.67 \\
\pm 11.547\end{array}$ & $\begin{array}{c}276.0 \\
\pm 16.73\end{array}$ & $\begin{array}{c}289.0 \\
\pm 14.93\end{array}$ & $\begin{array}{c}281.7 \\
\pm 14.52\end{array}$ & $\begin{array}{c}280.0 \\
\pm 14.14\end{array}$ \\
\hline $\begin{array}{l}\text { Alkalinity } \\
(\mathrm{mg} \cdot \mathrm{li}-1)\end{array}$ & $\begin{array}{l}220.0 \\
\pm 20.0\end{array}$ & $\begin{array}{r}225.0 \\
\pm 25.5\end{array}$ & $\begin{array}{l}228.0 \\
\pm 18.9\end{array}$ & $\begin{array}{l}220.0 \\
\pm 20.0\end{array}$ & $\begin{array}{c}240.0 \\
\pm 14.14\end{array}$ & $\begin{array}{c}245.4 \\
\pm 23.97\end{array}$ & $\begin{array}{c}251.8 \\
\pm 19.22\end{array}$ & $\begin{array}{l}225.0 \\
\pm 10.0\end{array}$ \\
\hline
\end{tabular}

${ }^{*}$ In a row, means followed by a common letter are not significantly different at $5 \%$ level by Tukey HSD and Scheffe; \pm indicates standard error of the mean (SEM)

\section{D I S C US S I O N}

Feed is a major input in cage aquaculture comprising of $70-80 \%$ of operating cost which limits the profitability of culture operations. It is also used in cage aquaculture in significant volume with serious implications on lake water quality in case of feeds wastage, hence, selection of appropriate feed type is important. Since the start of cage aquaculture in inland waters such as Taal Lake in Batangas,
Philippines, sinking feeds and slow-sinking feeds had been used traditionally for feeding fish but in recent years, extruded floating feeds had been introduced commercially. While some cage operators are now using floating feed types, a significant number of fish cage farmers still use sinking feeds with the basic assumptions that it results in better growth and size distribution at harvest. Extruded floating feed has been shown to exhibit better growth performance in several species (Aba et al. 2012; Ammar 2008; Chebbaki et 
al. 2010; Lee et al. 2016; Hematzade et al. 2013) but had shown no significant difference in some species (Limbu 2015; Misra et al. 2002). Whether floating or sinking feed type provides better culture performance and cost efficiency on $O$. niloticus and $C$. chanos reared in net cages remain to be validated.

Results of the present study indicated that extruded floating and extruded slow-sinking feeds had better growth performance than sinking feed for both $O$. niloticus and $C$. chanos. These results agree with the study of Ammar et al. (2008) and Abou-Zied (2015) which found a significantly better performance of $O$. niloticus fed extruded feeds over non-extruded feeds. Extruded floating feeds also performed better compared to non-extruded feeds in other species such as Oncorhynchus mykiss (Aba et al. 2012; Hematzade et al. 2013); Sparus aurata (Ammar 2008), Dicentrarchus labrax (Ammar 2008; Chebbaki et al. 2010), Mugil cephalus (Ammar 2008), and Anguilla japonica (Lee et al. 2016). The higher growth in fish fed extruded floating feed may be attributed to the efficiency of the feed type and lesser energy spent on feeding by the cultured fish. Extruded feeds are more efficient due to its higher digestibility and facilitate the inactivation and/or destruction of the heat-labile anti-nutritional factors (Delgado and Reyes-Jaquez 2018). Swimming is a very energy-demanding activity, and the energy expenditure of swimming at a fast speed during feeding may affect the weight gain of fish. In this study, the higher weight gain in fish fed floating feed type may be explained by the feeding behavior of $O$. niloticus and C. chanos on this feed type where fish feed effortlessly on the water surface with less swimming effort, therefore exerting low energy in feeding. The conserved energy of the fish was translated into fish flesh, thereby achieving more weight gain at harvest. In contrast, fish feeding on slow-sinking and sinking feeds were exerting more energy by dart swimming after the sinking feeds, hence, losing more energy in feeding that resulted in lesser weight gain.

Proximate analysis of the feeds used in the study showed crude protein, fiber, fat, moisture, and ash to be in the range required by both species. Among these parameters, only fat content was significantly different between feed treatments with higher fat content in sinking feeds than extruded floating feeds. In several species, the protein sparing effects of lipids had been reported (Orire and Sadiku 2011; Li et al. 2012; Hasan and Khan 2013; Yigit et al. 2002; Kikuchi et al. 2000) with higher levels of lipids in feeds resulting to higher weight gain in fish. This is in contrast with the results of this study which showed that fish fed on lower lipid level extruded floating feeds attained a higher growth rate than fish fed on sinking feed with higher lipid content. This may be attributed to the characteristics of the feed type and the manner in which fish exert energy to grab the feed. In floating feed type, fish exerted less energy to capture the feed due to its floating nature leading to conserved energy for growth. In the process, however, the decreased feeding activity resulted in higher body fat in fish. On the other hand, feeding on sinking feed type spent high energy in capturing food, thus, leaving less energy for growth resulting in lower weight gain.

The survival rate in the present study did not differ between feed treatments in both species but was relatively low in O. niloticus in comparison to percentage survival achieved in other studies at more than 85\% (Abou-Zied 2015; Ammar et al. 2008). The low survival rate may be attributed to the low mean dissolved oxygen levels in the experimental sites during the study period, which is typical of the dissolved oxygen level in the cage zones in Taal Lake (Querijero and Mercurio 2016). During these periods of low dissolved oxygen, inappetence, and mortality were recorded. Furthermore, gradual mortalities not related to low dissolved oxygen was also observed in O. niloticus. These were characterized by inappetence, disoriented, swirling swimming behavior, exophthalmia, and bent bodies that eventually die with very thin bodies. These clinical symptoms are similar with Streptococcal infection in O. niloticus described in the study of Sun et al. (2016), Pretto-Giordano et al. (2010), Asencios and Chaupe (2016), and Najiah et al. (2012). Such bacterial infection is normally correlated with high bacterial load in the water and high stocking density usually practiced in cage aquaculture. Although periodic mortality in O. niloticus was in few numbers, it occurred frequently over long periods until the harvest results to high accumulated mortality leading to low survival at the end of the study. On the other hand, the survival rate was high in C. chanos which is comparable to percentage survival attained in the study of Manomaitis and Cremer (2006). Few mortalities, however, were also recorded in C. chanos in all of the feed treatments which occurred at the later stage of the experiment and were noted to be caused by puncturing of the eye of the affected fish by other fishes during feeding activity.

The culture period to achieve market size in this study, eight months for O. niloticus and ten months for C. chanos, is relatively longer in comparison to the rearing of these species in other culture areas which may last for 4-6 months (Manomaitis and Cremer 
2006; Abu-Zied 2015; Ammar et al. 2008). This may be related to the periodic low levels of oxygen in the experimental cage areas that caused inappetence of fish during this adverse water condition, therefore reducing the growth rate of the experimental fish. At the optimum level of dissolved oxygen, a specific growth rate in $O$. niloticus may reach $3.8 \% /$ day (Makori et al. 2017) in comparison with the SGR in this study which ranged $2.16-2.22 \%$ /day at lower mean readings of dissolved oxygen. In the works of Tran-Duy et al. (2011), fish tended to reduce the energy requirements for maintenance as DO level declined. Feed intake in O. niloticus drops at below $5.5 \mathrm{mg} \cdot 1 \mathrm{i}-1$ dissolved oxygen in $>200 \mathrm{~g}$ fish and at 3 mg•li-1 for $<100 \mathrm{~g}$ fish with growth and metabolism adversely affected. Similarly, growth rate increased at a higher level of dissolved oxygen and lower growth at lower than optimum level was shown in the study on O. niloticus by Makori et al. (2017) and Abdel-Tawwab et al. (2015) and Tran-Duy et al. (2008).

Furthermore, the comparable feeds consumption but lower feed conversion ratio in $\mathrm{O}$. niloticus and C. chanos fed floating feed than fish fed sinking indicated the efficiency of the former over the latter feed type. In this study, the corresponding increase in weight at a lesser feed intake happened with fish fed floating feed type, similar with the results of Abu-Zied (2015) on O. niloticus fed extruded floating and extruded sinking feed. FCR is lower at floating feed type while inverse results occurred with sinking feed diets. FCR was also found to be better in fish fed extruded floating feed than sinking feeds and non-extruded feeds in other species (Aba et al. 2012; Ammar et al. 2008; Chebbaki et al. 2010; and Lee et al. 2016).

Biomass harvested in O. niloticus and $C$. chanos fed floating feeds was expectedly higher in floating feed treatments compared to sinking feeds as a result of the higher weight gain at final harvest with similar survival rate which is similar with the results of Abou-Zied (2015) and Ammar et al. (2008). Similar weight gain and percentage survival in slowsinking and sinking feed treatments resulted in similar biomass harvested in the two feed types. Contrary to the usual notion of cage farmers in Taal Lake that floating feeds will result in broken size with a large number of small-sized fish at harvest, the result of this study showed that the use of floating feeds in $O$. niloticus and C. chanos cage culture results in higher percentage of good marketable size at harvest. In the floating feed treatment, the majority of the fishes had an equal opportunity of feeding at the water surface, thus, resulting in a higher number of good sizes. At a very high fish density, however, this efficiency of floating feeds may decrease because the fish stocks may not be able to feed effectively at the water surface as a result of over-crowding. Appropriate stocking density must, therefore, be employed to assure the efficiency of the feed type. For fish fed sinking feed, the high percentage of smaller sized fish may be attributed to the inability of these fishes to compete with other faster swimming fishes while feeding after the sinking feeds. Fish in slow-sinking feed treatment had more good sized fish than sinking feed treatment because of better opportunities for feeding on slow-sinking feeds.

Cost analysis in the study showed fish fed floating feed had the highest profit and lowest in fish fed sinking feed. This is similar to the results of AbouZied (2015) for O. niloticus reared in earthen pond with net returns of EGP 38,475 (USD 2,146.14) for floating feed and EGP 21,300 (USD 1,188.12) for sinking feed and with Ammar et al. (2008) with EGP 14,538.25 (USD 810.95) and EGP 10,779.55 (US\$D601.29) for floating and sinking feed, respectively. The major difference in the net returns between the feed types is a result of the higher biomass harvested with lower FCR in the floating feed and slow-sinking type than in the sinking feed treatment. Moreover, the efficiency of the floating feed is also reflected in the higher volume of harvest at a lower feed cost. The higher biomass and lower feeds consumption and FCR of tilapia fed floating feed indicates the relative advantage of extruded floating feeds than sinking feeds used by cage farmers in Taal Lake. By using extruded floating feed instead of sinking feeds for $O$. niloticus culture, there will be a $35.61 \%$ increase in biomass harvest and a 30.15\% decrease in FCR. In C. chanos, the use of floating feeds resulted in an increase in biomass harvest by $22.69 \%$ and a decrease in FCR by $25.73 \%$. While floating feed type and slow-sinking feed are both extruded feeds, the use of floating feeds has relatively better growth performance and lower FCR compared to slow-sinking feeds. About $9.0 \%$ to $10.26 \%$ increase in weight gain was achieved using floating type compared to slow-sinking feed in both $O$. niloticus and C. chanos. FCR was also lower by $11.82 \%$ to $16.27 \%$. Mean weight of fish at 4 months period is less than $150 \mathrm{~g}$, thus harvesting the fish at this stage is not economically viable due to very low or even negative net returns. 


\section{CONCLUSION}

The use of extruded floating feeds revealed comparative advantage over commonly used sinking feeds and slow-sinking feeds with higher weight gain and biomass harvest, lower feed conversion ratio, and better size distribution at harvest. With extruded floating feeds, O. niloticus could attain $398.33 \mathrm{~g}$ in 246 days with an FCR of 1.39 while C. chanos could achieve $468.5 \mathrm{~g}$ in 301 days with an FCR of 1.8. The use of extruded floating feeds could decrease the use of feeds in cages by $30 \%$ in O. niloticus and by $19.4 \%$ in C. chanos at the same level of fish production in the lake, therefore minimizing the impact on the lake water environment. It could also lessen the feed cost by $29.44 \%$ in O. niloticus and $17.91 \%$ in C. chanos thus, higher net returns is attained. In effect, using extruded floating feeds in cage aquaculture does not only increase the profitability of the operations through the lower feed cost and higher biomass of harvest but also lessens the volume of feeds used in cage operations. By eliminating the use of sinking feeds, wastage of feeds due to sinking nature of the feeds is therefore prevented. However, appropriate stocking density should be followed to achieve the best results when using extruded floating feeds. Proper feeding management is also needed to avoid wastage of feeds and achieve maximum feed utilization. Based on the results of this study, it is therefore recommended that cage aquaculture such as Taal Lake utilize extruded floating feeds for a sustainable aquaculture production at higher net returns while minimizing negative impacts on the lake environment. Further study on proper feeding practices is also recommended to assess the appropriate methods for feeding using floating feeds.

\section{ACKNOW LE D G MEN T}

The authors express their deepest gratitude to their collaborating partners, Department of Environment and Natural Resources-Protected Areas Superintendent (DENR-PASu), Bureau of Fisheries and Aquatic Resources-Region 4A (BFAR-4A), and the local government units of Agoncillo, Batangas and Laurel, Batangas. The authors are also thankful to the anonymous reviewers of this paper. Special thanks to Ma. Lourdes Merilles for the figures and proofreading. Sincerest gratitude is also extended to Pedro del Mundo and Rosario del Mundo for their unwavering support to the project. Finally, the authors would like to acknowledge the efforts of their fish cage caretakers, Demetrio Artista, Maximo Masicat, and Doroteo Miranda.

\section{RE F E R E N C E S}

Aba M, Driss B, Khadija E, Mohammed B, Aziz M. 2012. Effects of Pressed and Extruded Foods on Growth Performance and Body Composition of Rainbow Trout (Oncorhynchus mykiss). Pakistan Journal of Nutrition 11(2): 104-109.

Abdel-Tawwab M, Hagras AE, Elbaghdady HAM, Monier MN. 2015. Effects of dissolved oxygen and fish size on Nile tilapia, Oreochromis niloticus (L.): growth performance, whole-body composition, and innate immunity. Aquaculture International 23(5): 1261-1274.

Abou-Zied RM. 2015. Effect of diet extruded type on growth performance, feed utilization and economic efficiency of Nile tilapia in commercial farms. Egyptian J. Nutrition and Feeds 18(1): 143-150.

Ammar AA. 2008. Effect of extruded and trash fish diets on growth performance and pond productivity of sea bream (Sparus aurata), the sea bass (Dicentrarchus labrax) and the flathead grey mullet (Mugil cephalus) reared in polyculture system in earthen ponds. Egypt. J. Aquat. Biol. \& Fish. 12(1): 43-58.

Ammar AA, Abd-Elgawad AS, Salama AA. 2008. Effect of extruded and non-extruded fish pellet on growth performance and total production of nile tilapia and grey mullet fingerlings reared in a polyculture system in earthen ponds. 8th International Symposium on Tilapia in Aquaculture 2008. 823-835 p.

AOAC. 1990. Association of Official Analytical Chemists, Official Methods of Analysis Washington, DC., USA: Argent Laboratories Press.

Asencios YO, Chaupe NS. 2016. First report of Streptococcus agalactiae isolated from Oreochromis niloticus in Piura, Peru: Molecular identification and histopathological lesions. Aquaculture Reports 4: 74-79. 
BFAR Philippine Fisheries Profile 2016. Bureau of Fisheries and Aquatic Resources. PCA Bldg., Elliptical Road, Diliman, Quezon City. [cited 2018 Apr 15]. Available from: https://www.bfar. da.gov.ph/files/img/photos/2014FisheriesProfile (Finalcopy).pdf

Chebbaki K, Akharbach H, Talbaoui E, Abrehouch A, Ait ali A, Sedki S, Ben Bani A, Idaomar M. 2010. Effect of fish meal replacement by protein sources on the extruded and pressed diet of European sea bass juvenile (Dicentrarchus labrax). Agriculture and Biology Journal of North America 1(4): 704710 .

Delgado E, Reyes-Jaquez D. 2018. Extruded Aquaculture Feed: A Review, Extrusion of Metals, Polymers, and Food Products Sayyad Zahid Qamar, IntechOpen [Internet]. [cited 2018 Apr 15]. Available from https://intechopen. com. DOI:10.5772/intechopen.69021.

Food and Agriculture Organization (FAO). 2017. FAO Yearbook. Fishery and Aquaculture Statistics 2015. Rome, Italy.

Hasan AJZ, Khan U. 2013. Protein sparing effect and the efficiency of different compositions of carbohydrates, lipids and proteins on the growth of rohu (Labeo rohita) fingerlings. World Journal of Fish and Marine Sciences. 5(3): 244-250.

Hematzade A, Taati MM, Raissy M. 2013. Effects of extrusion of diet on growth parameters of rainbow trout (Oncorhyncus mykiss). $\mathrm{ABAH}$ Bioflux 5 (2): 127-131.

Hilton JW, Cho SJ, Slinger CY. 1981. Effect of extrusion processing and stream pelleting diets on pellet durability pellet water absorption and physiological response of rainbow trout, (Salmo gairdneri R.). Aquacult. 25: 185-194.

Johnsen FA, Wandsvik A. 1991. The impact of high energy diets on pollution control in the farming industry. In: Cowey $\mathrm{CB}$, Cho $\mathrm{CY}$, editors. Proceedings of the First International Symposium on Nutrition Strategies in Management of Aquaculture Waste.Guelph, Ontario, 5-8 June 1990. Univ. of Guelph. Ontario. Canada. p. 51-63.

Jescovitch LN, Ullman C, Rhodes M, Davis DA.
2017. Effects of different feed management treatments on water quality for Pacific white shrimp Litopenaeus vannamei. Aquaculture Research [Internet]. [Cited 2018 Apr 15]; 49 (1). Available from: https://onlinelibrary.wiley.com/ doi/full/10.1111/are.13483.

Kikuchi K, Sugita H, Watanabe T. 2000. Effect of dietary protein and lipid levels on growth and body composition of Japanese flounder. Suisanzoshoku. 48(3): 537-543.

Lee S, Moniruzzaman M, Yun H, Park Y, Mann J, Bai SC. 2016. Comparative studies on effects of extruded pellets and dough type diets on growth, body composition, hematology and gut histology of juvenile Japanese eel, Anguilla japonica (Temminck et Schlegel). J. Fish. Aquat. Sci. [Internet]. [cited 2018 Apr 15]; 11(5). Available from: https://www.research gate.net/ publication/304396857. DOI: 103923/jfas.2016.

Li X, Jiang Y, Liu W, Ge X. 2012. Protein-sparing effect of dietary lipid in practical diets for blunt snout bream (Megalobrama amblycephala) fingerlings: effects on digestive and metabolic response. Fish Physiol Biochem. 38(2): 529-541.

Limbu SM. 2015. The effect of floating and sinking diets on growth performance, feed conversion efficiency, yield and cost-effectiveness of African sharptooth catfish, Clarias gariepinus reared in earthen ponds. International Journal of Fisheries and Aquatic Studies 2(5): 253-259.

Makori AJ, Abuom PO, Kapiyo R, Anyona DN, Dida GO. 2017. Effects of water physico-chemical parameters on tilapia (Oreochromis niloticus) growth in earthen ponds in Teso North SubCounty, Busia County. Fisheries and Aquatic Sciences [Internet]. [cited 2018 Apr 15]; 20:30. Available from: https://fas.biomedcentral.com/ articles/. DOI: 10.1186/s41240-017-0075-7

Manomaitis L, Cremer MC. 2006. Growth performance of milkfish fed soy-based feed in low volume high density cages in Majuyod Bay, Philippines. Results of ASA-IM/Soy-inAquaculture 2006 Feeding Demonstration Project. [Internet]. [cited 2018 Apr 15]. Available from: http://www.soyaqua.org/sites/default/files/ reports/06milkfish manjuyodbayrpresultspdf. pdf 
Mmochi AJ, Dubi Am, Mamboya FA, Mwandya AW. 2002. Effects of fish culture on water quality of an integrated mariculture pond system. Western Indian Ocean J. Mar. Sci. 1(1): 53-63.

Misra CK, Sahu NP, Jain KK. 2002. Effect of extrusion processing and steam pelleting diets on pellet durability, water absorption and physical response of Macrobrachium rosenbergii. AsianAustralasian Journal of Animal Sciences 15(9): 1354-1358.

Najiah M, Aqilah NI, Lee KL, Khairulbariyyah Z, Mithun S, Jalal KCA, Shararom-Harrison F, Nadirah M. 2012. Massive mortality associated with Streptococcus agalactiae infection in cagecultured hybrid tilapia Oreochromis niloticus in Como River, Kenyir Lake, Malaysis. Journal of Biological Sciences 12: 438-442.

Orire AM, Sadiku SOE. 2011. Protein sparing effects of lipids in the practical diets of Oreochromis niloticus (Nile tilapia). Nigerian Journal of Basic and Applied Science. 19(1): 142-150.

Philippine Statistics Authority (PSA). 2016. Philippine Fisheries Situationer 2016. Philippine Statistics Authority. Quezon City, Philippines. [cited 2018 Apr 15].pp 47. Available from: https://psa.gov.ph/ sites/default/files/FisheriesSituationer2016_0. pdf.

Pretto-Giordano LG, Muller EE, de Freitas JC, de Silva VG. 2010. Evaluation on the pathogenesis of Streptococcus agalactiae in Nile Tilapia (Oreochromis niloticus). Brazilian Archives of Biology and Technology 53(1): 87-92.

Querijero BL, Mercurio A. 2016. Water Quality in Aquaculture and Non-Aquaculture sites in Taal, Lake, Batangas, Philippines. Journal of Experimental Biology and Agricultural Sciences $4(1)$.

Robert N, Le Gouvello R, Mauviot JC, Arroyo F, Aguirre P, Kaushik SJ. 1993. Use of extruded diets in intensive trout culture: effects of protein to energy on growth, nutrient utilization and on flesh and water quality. In: Kaushik SJ and Laque P, editors. Fish Nutrition in Practice. Les Colloques No. 61. INRA edn. Versailles Codex. France. p. 497-500.
Sun J, Fang W, Ke B, He D, Liang Y, Ning D, Tan H, Peng H, Wang Y, Ma Y, Ke C. 2016. Inapparent Streptococcus agalactiae infection in adult/ commercial tilapia. Scientific Reports [Internet]. [cited 2018 Apr 15]; 6: 26319. Available from https://www.ncbi.nlm.nih.gov/pmc/articles/ PMC4877633/. DOI:10.1038/srep26319.

Tacon AGJ, Forster IP. 2003. Aquafeeds and the environment: policy implications. Aquaculture 226: 181-189.

Taal Volcano Protected Landscape (TVPL). 2010. Taal Volcano Protected Landscape (TVPL) Management Plan 2010-2020. Department of Environment and Natural Resources, Protected Areas Superintendent (PASu) Office. Talisay, Batangas.

Tran-Duy A, van Dam AA, Schrama JW. 2011. Feed intake growth and metabolism of Nile tilapia (Oreochromis niloticus) in relation to dissolved oxygen concentration. Aquaculture Research 43(5): 730-744.

Venou B, Alexis MN, Fountoulaki E, Nengas I, Apostolopoulou M, Castritsi-Cathariou I. 2003. Effect of extrusion of wheat and corn on gilthead sea bream (Sparus aurata) growth, nutrient utilization efficiency, rates of gastric evacuation and digestive enzyme activities. Aquaculture. 225: 207-223.

White P. 2013. Environmental consequences of poor fed quality and feed management. In: Hasan MR and New MB, editors. On-farm feeding and feed management in aquaculture. FAO Fisheries and Aquaculture Technical Paper No. 583. Rome, FAO. P. 553-564.

Xie S, Yang Y, Han D, Zhang S. 2018. Development in Feeds in Chinese Aquaculture. In: Gui JF, Tang Q, Li Z, Lin J, de Silva SS, editors. Aquaculture in China: Success Stories and Modern Trends. Wiley Blackwell Press. p. 431-450.

Yigit M, Yardim O, Koshio S. 2002. The protein sparing effects of high lipid levels in diets for rainbow trout (Onchorynchus mykiss, W. 1792) with special reference to reduction of total nitrogen excretion. The Israeli Journal of AquacultureBamidgeh. 54(2): 79-88. 